\title{
The GT biplot analysis of green bean traits
}

\author{
Tâmara Rebecca Albuquerque de Oliveira ${ }^{1^{*}} \odot$ Geraldo de Amaral Gravina $^{1}$ \\ Gustavo Hugo Ferreira de Oliveira ${ }^{2}$ Kleberson Cordeiro Araújo ${ }^{3}$ \\ Lanusse Cordeiro de Araújo ${ }^{1}$ Rogério Figueiredo Daher ${ }^{1}$ Marcelo Vivas ${ }^{1}$ \\ Lilia Marques Gravina ${ }^{1}$ Derivaldo Pureza da Cruz ${ }^{1}$
}

${ }^{1}$ Centro de Ciências e Tecnologias Agropecuárias (CCTA), Universidade Estadual do Norte Fluminense Darcy Ribeiro (UENF), 28013-602, Campos dos Goytacazes, RJ, Brasil. E-mail: tamara_rebecca@hotmail.com. "Corresponding author.

${ }^{2}$ Núcleo de graduação de agronomia (NEAS), Universidade Federal de Sergipe (UFS), Campus do Sertão, Nossa Sen hora da Glória, SE, Brasil.

\begin{abstract}
The green bean (Phaseolus vulgaris L.) is a nutrient-rich vegetable much appreciated; although, little studied, in Brazil. The aim of the current study was to investigate the nature of traits of interest, as well as to select plants for the green bean breeding program based on genotype vs. trait biplot analysis. The experiment followed a randomized block design, with 4 repetitions and 17 genotypes. Analysis of variance, principal component analysis and biplot charts were performed to analyze the number of pods per plant, the number of seeds per pod, the number of seeds per plant, seed weight per plant, 100-seed weight, as well as grain and pod yields. The analysis of variance showed genetic variability between genotypes. Grain yield, pod yield and seed weight per plant were highly correlated. The number of seeds per pod was negatively correlated with pod weight, grain weight and with seed weight per plant. Lines Feltrin and UENF 14-30-3 were indicated to increase gains in variables such as grain yield and pod yield.
\end{abstract}

Key words: Phaseolus vulgaris L., multivariate analysis, genotypes $x$ traits.

Análise GT biplot para características de feijão-vagem

RESUMO: O feijão-vagem (Phaseolus vulgaris L.) é uma hortaliça rica em nutrientes, muito apreciada no Brasil, mas pouco estudada. O objetivo deste trabalho foi conhecer a natureza das características de interesse e selecionar plantas, para seguir o programa de melhoramento de feijão-vagem, por meio da análise biplot de genótipo x característica. O delineamento utilizado foi de blocos casualizados com quatro repetições e 17 genótipos. Foram feitas análise de variância, análise de componentes principais e os gráficos bilots para número de vagem por planta, número de sementes por vagem, número de sementes por planta, peso de sementes por planta, peso de 100 sementes, produtividade de grãos e produtividade de vagem. A análise de variância mostrou existência de variabilidade genética entre os genótipos. Produtividade de grãos, produtividade de vagens e peso de sementes por plantas são altamente correlacionados. O número de sementes por vagem tem correlação negativa com peso de vagem, peso de grãos e peso de sementes por planta. Os genótipos Feltrin e UENF 14-30-3 foram indicadas para obtenção de ganhos para as variáveis produtividade de grãos e produtividade de vagem.

Palavras-chave: Phaseolus vulgaris L., análise multivariada, genótipos x característcas.

\section{INTRODUCTION}

Green beans are rich in fiber, phosphorus, fluorine, potassium, calcium, iron, as well as in A, C and $\mathrm{B}$ vitamins. In addition, the species is important worldwide due to its commercial exploitation. It has nutritional qualities that make it an excellent human nutrition component; moreover, it can be consumed as seeds and as unripe pods (FILGUEIRA, 2013).

Although, it is a very appreciated vegetable, the contribution from breeding programs in Brazil is not significant when it comes to the development of green bean lines, since there is not much information or great contributions regarding the aims of these programs. However, the lack of information about green beans hampers programs focused on genetically improving this crop, since it is necessary knowing the nature of the traits to be improved.

Some analyses allow studying the correlation between traits. According to PARAMESH et al. (2016), the simple correlation analysis describes the relation between two variables. Conversely, 
the multivariate analysis has the advantage of simultaneously using all the variables to interpret the dataset, which is the reason why it has been used in studies about different cultures (ATNAF et al., 2017; FARID et al., 2017; MATHOBO \& MARAIS, 2017).

Genotypes vs. traits biplot analysis (GT Biplot) stands out among the multivariate methodologies, since it assesses genotypes based on multiple traits and identifies those superior to the desired variables, which may be used as parents in breeding programs or even as possible commercial cultivars. In addition, this analysis enables the rapid and practical visualization of the genetic correlation between traits. It allows detecting less important (redundant) traits, as well as identifying the most appropriate ones for the indirect selection of a desirable trait (MOHAMMADI \& AMRI, 2013).

In light of the foregoing, the aim of the current study was to investigate the genetic nature of the traits of interest, as well as to select plants for the green bean breeding program.

\section{MATERIALS AND METHODS}

Seventeen green bean genotypes (Table 1) of indeterminate growth habit were assessed in 2011, 2012 and 2013, in Cambuci (latitude: 21 ${ }^{\circ} 34^{\prime} 31^{\prime \prime} \mathrm{S}$, longitude: 41 ${ }^{\circ} 54^{\prime} 40^{\prime \prime} \mathrm{W}$ and altitude: $35 \mathrm{~m}$ ) and Bom Jesus de Itabapoana (latitude: $21^{\circ} 08^{\prime} 02^{\prime \prime} \mathrm{S}$, longitude: $41^{\circ} 40^{\prime} 47^{\prime}$ ' W and altitude: $88 \mathrm{~m}$ ) Counties, Northwestern Rio de Janeiro State.

The experiment followed a randomized block design, with four repetitions, in the bifactorial (17 genotypes x 2 environment); plants were individually assessed in each plot. The plots comprised ten plants, three seeds per pit, and spacing $1.0 \times 0.5 \mathrm{~m}$.

Table 1 - Identification of 17 green bean lines assessed in Cambuci and Bom Jesus de Itabapoana counties. Rio de Janeiro, 2011, 2012 and 2013.

\begin{tabular}{lccl}
\hline N. & Parents & N. & Parents \\
\hline 1 & UENF 1445 & 10 & UENF 7-12-1 \\
\hline 2 & Feltrin & 11 & UENF 7-14-1 \\
3 & Top Seed Blue Line & 12 & UENF 7-20-1 \\
\hline 4 & UENF 7-3-1 & 13 & UENF 9-24-2 \\
5 & UENF 7-4-1 & 14 & UENF 14-30-3 \\
6 & UENF 7-5-1 & 15 & UENF 14-4-3 \\
7 & UENF 7-6-1 & 16 & UENF 14-6-3 \\
\hline 8 & UENF 7-9-1 & 17 & UENF 15-23-4 \\
\hline 9 & UENF 7-10-1 & & \\
\hline
\end{tabular}

Thinning was carried out ten days after planting and left one plant per pit. Plants were tutored with bamboo and wire, fifteen days after emergence. Fertilizations were carried out according to soil analysis. The cultural and phytosanitary treatments were applied in compliance with the recommendations for the culture, according to FILGUEIRA (2013), and irrigation was done through sprinkling.

The herein analyzed variables were NPP: number of pods per plant - determined by counting the number of pods per plant; NSP: number of seeds per pod - determined by counting the number of seeds per pod; NSPl: number of seeds per plant - determined by counting the number of seeds per plant; SWP: seed weight per plant - total weight in grams ( $\mathrm{g}$ ) of seeds per/ plant measured through precision scale; 100SW: 100seed weight - samples randomly selected and weighted in a duly-calibrated precision scale; GY: grain yield quantification of the total weight in grams $(\mathrm{g})$ of the grains from each plant, after pod threshing, by means of precision scale; and PY: pod yield - quantification of the total weight in grams $(\mathrm{g})$ of the pods from each plant, by means of precision scale.

Analysis of variance where realized $(\mathrm{p}<0.05)$ and the principal component $(\mathrm{PC})$ analysis was applied to assess the herein collected data. The first two PCs were used to group the genotypes, whose values were used to generate the biplots; PC1 was used on the horizontal axis, whereas PC2 was used on the vertical axis. The statistics analysis were performed in the R software - ggplot2 package (WICKHAM, 2009).

\section{RESULTS AND DISCUSSION}

The significant effect from the interaction between genotypes and locations showed the differentiated performance of the lines in relation to environmental changes, fact that corroborated several studies, which assessed common bean genotypes in different Brazilian regions (TORRES et al., 2016; TORRES FILHO et al., 2017).

There was significant effect between genotypes on all the variables, except for pod yield (PY) in 2012 and for the number of seeds per plant (NSPl) in 2013 (Table 2). Conversely, the significant difference between genotypes indicated genetic variability between green bean lines. It is worth emphasizing that the means of the studied traits were different in each genotype; thus, the classification of the aforementioned lines may change according to the analyzed variable.

In light of the foregoing, it is worth conducting a detailed study about the behavior of these lines in order to help selecting genotypes 
Table 2 - Mean square estimates of variables analyzed in 17 green bean lines assessed in Cambuci and Bom Jesus de Itabapoana counties Rio de Janeiro, 2011, 2012 and 2013.

\begin{tabular}{|c|c|c|c|c|c|c|c|c|}
\hline \multirow{3}{*}{$\begin{array}{l}\text { Sources of } \\
\text { variation }\end{array}$} & \multirow{3}{*}{ DF } & \multirow{2}{*}{\multicolumn{7}{|c|}{ }} \\
\hline & & & & & & & & \\
\hline & & NPP & NSP & NSPl & SWP & $100 \mathrm{SW}$ & GY & PY \\
\hline Block(Loc) & 6 & $728.42^{*}$ & 0.58 & $64381.31^{*}$ & $7285.99^{*}$ & 19.05 & $2915782.34^{*}$ & $316.10^{*}$ \\
\hline Loc & 1 & $1120.68^{*}$ & 1.54 & $115929.84^{*}$ & 5510.56 & $133.41^{*}$ & 2205651.06 & $2821.82^{*}$ \\
\hline Gen & 16 & $480.95^{*}$ & $0.83^{*}$ & $29767.53^{*}$ & $7598.14^{*}$ & $161.05^{*}$ & $3039071.67^{*}$ & $95.84^{*}$ \\
\hline Gen $x$ Loc & 16 & 158.18 & 0.47 & 12898.89 & 2038.91 & 9.86 & 815547.37 & $66.64^{*}$ \\
\hline Residues & 96 & 144.04 & 0.40 & 13241.82 & 1953.50 & 10.79 & 781411.40 & 35.32 \\
\hline \multicolumn{9}{|c|}{ 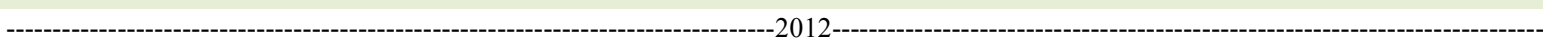 } \\
\hline Block & 6 & 27.27 & 0.70 & 5289.16 & 926.61 & 3.18 & 370577.44 & $92.81^{*}$ \\
\hline Gen & 16 & $1002.46^{*}$ & $0.90^{*}$ & $59066.45^{*}$ & $5507.25^{*}$ & $76.89^{*}$ & $2202474.12^{*}$ & 31.77 \\
\hline Residue & 48 & 148.59 & 0.39 & 11435.53 & 1302.57 & 7.75 & 521178.41 & 23.14 \\
\hline \multicolumn{9}{|c|}{ } \\
\hline Block & 6 & $1032.71^{*}$ & 0.31 & $80153.60^{*}$ & $10772.29^{*}$ & 12.33 & $4307682.30^{*}$ & $36.08^{*}$ \\
\hline Gen & 16 & $269.43^{*}$ & $2.74^{*}$ & 15500.90 & $2707.98^{*}$ & $95.28^{*}$ & $1083346.04^{*}$ & $41.76^{*}$ \\
\hline Residue & 48 & 128.42 & 0.36 & 9558.64 & 1088.62 & 7.42 & 435465.47 & 12.30 \\
\hline
\end{tabular}

Loc: location; Gen: genotype; NPP: number of pods per plant; NSP: number of seeds per pod; NSP1: number of seeds per plant; SWP: seed weight per plant; 100SW: 100-seed weight; GY: grain yield; PY: pod yield.

presenting traits of interest to be used in green bean breeding programs.

The genotypes vs. traits biplot (GT Biplot) analysis represented $78.83 \%$ of the total trait variation between lines (Figure 1A). According to YANG et al. (2009), the first two PCs should explain more than $60 \%$ of data variation. The current results showed that most of the total variation was explained through the first two PCs. It suggested that the biplot charts have efficiently represented data variability, fact that enabled the safe and clear interpretation of the herein studied phenomena.

The biplot chart presents a set of perpendicular lines, which divide it in several groups to characterize the genotypes (YAN, 2001). According to PARAMESH et al. (2016), genotypes located in the biplot vertices may be explored in breeding programs in order to help developing varieties responsive to the traits of interest. Thus, genotypes located in the biplot vertex, also known as vertex genotypes, show the best performance in one or several traits. On the other hand, genotypes located within the polygon are the least responsive to these traits.

Therefore, the six herein studied traits were divided in four groups. The first group comprised grain yield (GY), seed weight per plant (SWP), pod yield (PY), number of seeds per plant (NSPl) and number of pods per plant (NPP); L2 was the most responsive to these traits, and it was followed by lines
Top Seed Blue Line (3), UENF 7-4-1 (5) and UENF 14-30-3 (14); UENF 14-30-3 (14) showed the highest pod yield. The second group consisted only of the number of pods per plant (NPP); UENF 7-5-1 (6), UENF 7-6-1 (7) and UENF 7-14-1 (11) were the most responsive lines. Only UENF 7-20-1 (12) stood out in the third group, which was represented by the number of seeds per pod (NSP). The fourth group was formed by the trait 100 -seed weight $(100 \mathrm{SW})$. However, it did not present any line responsive to this trait.

Genotypes that give raise to vertices, but do not hold grouped traits, are unfavorable to the groups of studied traits. Thus, they are not indicated for breeding programs focused on increasing the expression of these traits. Therefore, the following lines were considered inefficient in the herein studied traits: UENF 1445 (1), UENF 7-3-1 (4), UENF 7-9-1 (8), UENF 7-10-1 (9), UENF 7-12-1 (10), UENF 9-24-2 (13), UENF 14-4-3 (15), UENF 14-6-3 (16) and UENF 15-23-4 (17).

Figure 1B shows the representativeness and discriminating capacity of each genotype towards the studied traits. The circle on the line crossing the coordinate axis represents the mean of the traits. The distance between the genotype and the mean measures the representativeness power; thus, the closer to the mean, the greater the genotype representativeness towards the trait. Conversely, the length of the projection from a line towards the $\mathrm{Y}$ axis (straight 

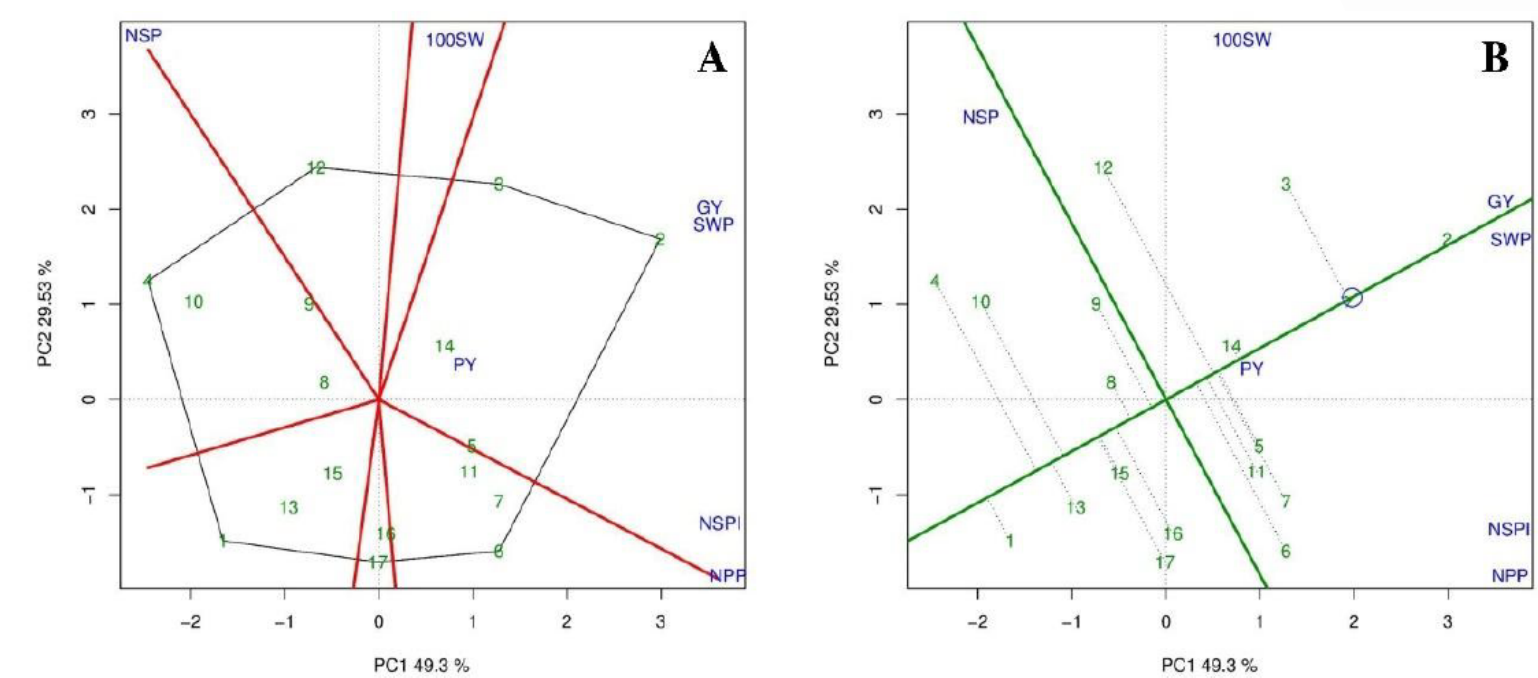

Figure 1 - GT biplot representing: (A) the "which-won-where" graph and (B) means x stabilities, indicating the ranking of 17 green bean lines according to the traits. NPP: number of pods per plant; NSP: number of seeds per pod; NSPl: number of seeds per plant; SWP: seed weight per plant; 100SW: 100-seed weight; GY: grain yield; and PY: pod yield; 1: UENF 1445; 2: Feltrin; 3: Top Seed Blue Line; 4: UENF 7-3-1; 5: UENF 7-4-1; 6: UENF 7-5-1; 7: UENF 7-6-1; 8: UENF 7-9-1; 9: UENF 7-10-1; 10: UENF 7-12-1; 11: UENF 7-14-1; 12: UENF 7-20-1; 13: UENF 9-24-2; 14: UENF 14-30-3; 15: UENF 14-4-3; 16: UENF 14-6-3; 17: UENF 15-23-4.

line passing through the origin) shows the lines discrimination (YAN, 2001). Therefore, lines such as Feltrin (2), Top Seed Blue Line (3), UENF 14-30-3 (14), UENF 7-6-1 (7), UENF 7-4-1 (5), UENF 7-20-1 (12), UENF 7-14-1 (11) and UENF 7-5-1 (6) showed good representativeness; however, only Feltrin (2) and UENF 14-30-3 (14) showed good discrimination. The other lines showed means below the general mean.

The ideal genotype is the one presenting high means in all the traits and it is identified based on the length of the vector; thus, the longer the PC1 and PC2 without projections and the closer to the concentric circle, the better the genotype (SANTOS et al., 2017) (Figure 2A). Based on the herein studied traits, Feltrin was considered the ideal line, and it was followed by the Top Seed Blue Line. Genotypes were classified in the following order according to their performances: Feltrin (2) > Top Seed Blue Line (3) > UENF 14-30-

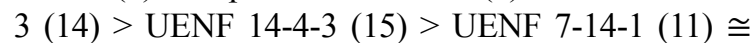

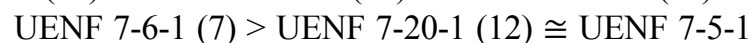
(6) > UENF 7-10-1 (9) $\cong$ UENF 7-9-1 (8).

The degree of association between two traits (Figure 2B), which was based on multiple traits compared between genotypes and on the identification of genotypes that could be used as parents in breeding programs because they were particularly good in certain aspects. According to this biplot, the cosine of the angles formed by the connected vectors (lines), in each variable, represents the degree of association. Consequently, acute angles $\left(<90^{\circ}\right)$ are positively correlated, whereas obtuse angles $\left(>90^{\circ}\right)$ are negatively correlated. The vectors forming a right angle $\left(=90^{\circ}\right)$ are uncorrelated, whereas those forming $180^{\circ}$ angles are strongly negatively correlated.

The formed angles showed that grain yield, pod yield and seed weight per plant were highly correlated, thus indicating that the higher the GY or the SWP value, the higher the PY.

In addition, the aforementioned variables presented correlation levels similar to that of other variables. Therefore, 100SW, NSPl and NPP showed positive correlation with GY, PY and SWP. These results corroborate studies that assessed the correlation between these agronomic variables in different bean genotypes (GASIM et al., 2015; GONÇALVES et al., 2017).

Number of seeds per pod showed negative correlation with pod weight, grain weight, and with seed weight per plant. Therefore, lines presenting the highest number of seeds per pod may be less productive; thus, they should not be indicated for genotype selections focused on obtaining gains in seed or pod yield, since there is no evidence of linear correlation with this trait. Based on interrelations, it is suggested that SWP may be the best variable for the obtainment of genotypes with dual aptitude. Thus, the selection based on the seed weight per plant may 


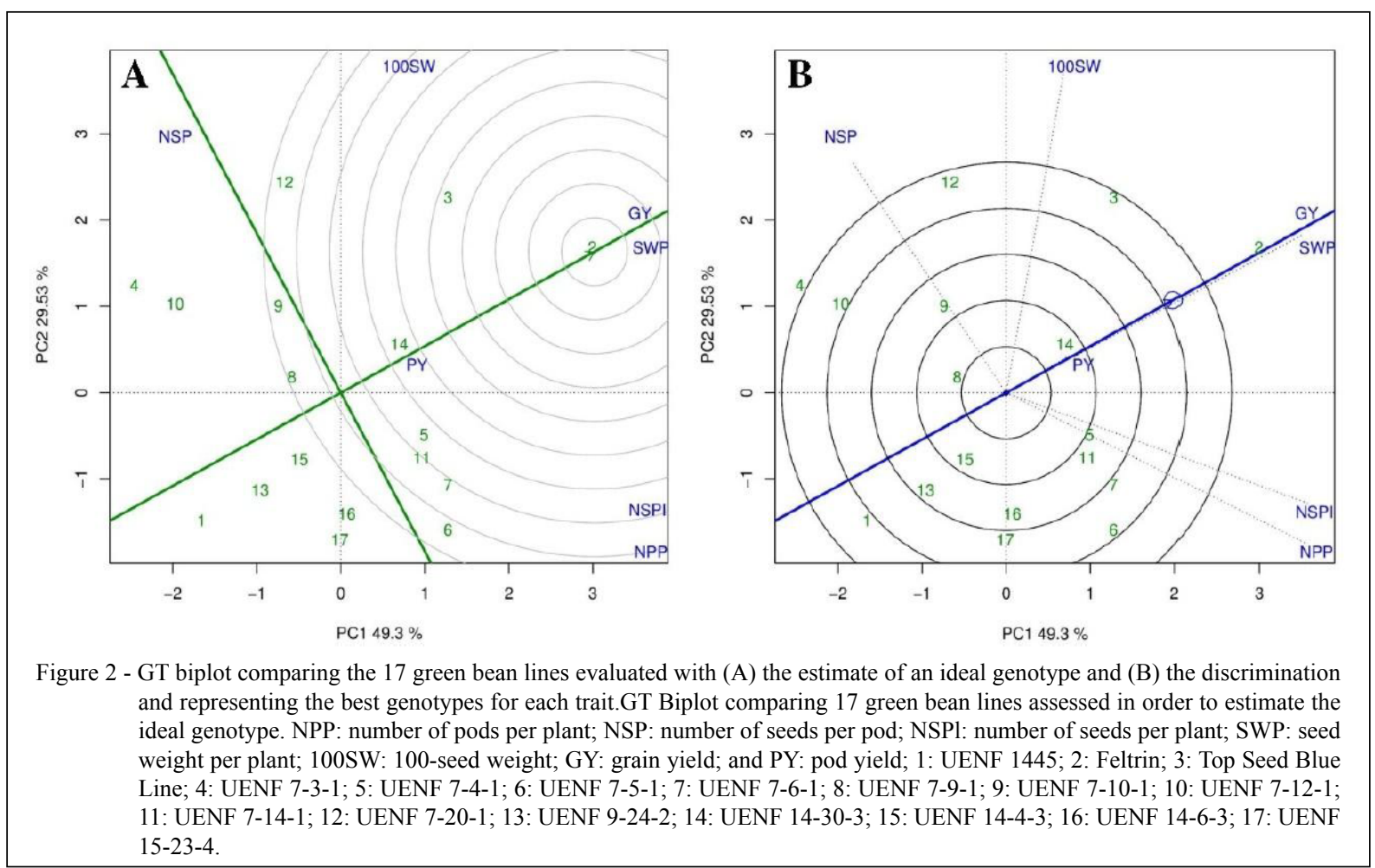

lead to gains when the breeding program is focused on developing genotypes able to present high grain and pod yield.

Feltrin and UENF 14-30-3 (14) stood out in GY, PY and SWP, if one takes into consideration the genotype selection based on the variable the genotypes correlate with. Thus, these lines could be used as parents in breeding programs focused on obtaining lines able to present high grain and pod yield. UENF 7-4-1 (5), UENF 7-14-1 (11), UENF 7-6-1 (7) and UENF 7-5-1 (6) stood out in NSPl and NPP. UENF 7-3-1 (4), UENF 7-9-1 (8), UENF 7-10-1 (9), UENF 7-12-1 (10) and UENF 7-20-1 (12) showed the best performances in NSP, whereas Top Seed Blue Line (3), UENF 7-20-1 (12) and UENF 14-30-3 (14) stood out in 100SW.

\section{CONCLUSION}

The GT biplot is an excellent tool used to visualize correlations between green bean traits and is recommended for the reliable identification of green bean lines able to present high pod and grain yield. Moreover, the variable seed weight per plant was identified as an important trait for pod and grain yield.

\section{ACKNOWLEDGEMENTS}

Thanks to Coordenação de Aperfeiçoamento de Pessoal de Nível Superior (CAPES), Fundação Carlos Chagas Filho de Amparo a Pesquisa do Estado do Rio de Janeiro (FAPERJ) and Conselho Nacional de Desenvolvimento Científico e Tecnológico (CNPq) for the granted scholarship.

\section{DECLARATION OF CONFLICTING INTERESTS}

The authors declare no conflict of interest. The founding sponsors had no role in the design of the study; in the collection, analyses, or interpretation of data; in the writing of the manuscript, and in the decision to publish the results.

\section{REFERENCES}

ATNAF, M. et al. Genotype by trait biplot analysis to study associations and profiles of Ethiopian white lupin ('Lupinus albus' L.) landraces. Australian Journal of Crop Science, v. 11, n. 1, p. 55, 2017. Available from: <http://www.cropj.com/ tiruneh_11_1_2017_55_62.pdf>. Acessed: Set. 20, 2017. doi: 10.21475/ajes. $2017 . \overline{1} 11 . \overline{0} 1 . p n e 226$.

FARID, M. et al. Response to selection for improved nitrogen fixation in common bean (Phaseolus vulgaris L.). Euphytica, v. 213, n. 4, p. 99, 2017. Available from: <https://link.springer.com/article/10.1007/ s10681-017-1885-5>. Acessed: Set. 20, 2017. doi: 10.1007/s1068. 
FILGUEIRA, F.A.R. Novo manual de olericultura: agrotecnologia moderna na produção e comercialização de hortaliças. Viçosa: UFV, 2013. 421p.

GASIM, S. et al. Yield and quality attributes of faba bean inbred lines grown under marginal environmental conditions of Sudan. Food science \& nutrition, v. 3, n. 6, p. 539-547, 2015. Available from: <https://www.ncbi.nlm.nih.gov/pmc/articles/PMC4708656/>. Acessed: Set. 10, 2017. doi: 10.1002/fsn3.245.

GONCALVES, D.D.L. et al. Correlação genética e análise de trilha de feijão comum coletados em Cáceres-MT, Brasil. Ciência Rural, v. 47, n. 8, p. 01-07, 2017. Available from: <http://revistas.bvs-vet. org.br/crural/article/view/37219/41830>. Acessed: Set. 20, 2017. doi: $10.1590 / 0103-8478 \mathrm{cr} 20160815$

MOHAMMADI, R.; AMRI, A. Genotype $\times$ environment interaction and genetic improvement for yield and yield stability of rainfed durum wheat in Iran. Euphytica, v. 192, n. 2, p. 227-249, 2013. Available from: $<$ https://doi.org/10.1007/s10681-012-0839-1>. Acessed: Set. 7, jul. 2017. doi: 10.1007/s10681-012-0839-1.

MATHOBO, R.; MARAIS, D. Evaluation of genotype x environment interaction using GGE-biplot on dry beans ('Phaseolus vulgaris ' L.) in Limpopo province of south Africa. Australian Journal of Crop Science, v. 11, n. 5, p. 506-515, 2017. Available from: $<$ https:// repository.up.ac.za/bitstream/handle/2263/61566/Mathobo_Evaluation_2017.pdf?sequence $=1 \&$ isAllowed $=\mathrm{y}>$. Acessed: Set. 12, 2017. doi: 10.21475/ajcs.17.11.05.p303.

PARAMESH, M. et al.. GT biplot analysis for yield and drought related traits in mung bean (Vigna radiata L. Wilczek). Electronic Journal of Plant Breeding, v. 7, n. 3, p. 538-543, 2016. Available from: $<$ http://ejplantbreeding.com/index.php?journal=EJPB\&page=articl e\&op=view\&path $\% 5 \mathrm{~B} \% 5 \mathrm{D}=776 \&$ path $\% 5 \mathrm{~B} \% 5 \mathrm{D}=709>$. Acessed: Set. 12, 2017. doi: 10.5958/0975-928X.2016.00069.7.

SANTOS, A.D. et al. GGE Biplot projection in discriminating the efficiency of popcorn lines to use nitrogen. Ciência e Agrotecnologia, v. 41 , n. 1 , p. $22-31,2017$. Available from: $<$ http://www.scielo.br/ pdf/cagro/v41n1/1981-1829-cagro-41-01-00022.pdf $>$. Acessed: Set. 5, 2017. doi: 10.1590/1413-70542017411030816.

TORRES, F.E. et al. Adaptability and phenotypic stability of semiprostate cowpea genotypes in Mato Grosso do Sul. Bioscience Journal, v. 32, n. 6, 2016. Available from: <http://www.seer.ufu.br/ index.php/biosciencejournal/article/view/32813/19327>. Acessed: Set. 7. 2017. doi: 10.14393/BJ-v32n6a2016-32813.

TORRES FILHO, J. et al. Genotype by environment interaction in green cowpea analyzed via mixed models. Revista Caatinga, v. 30, n. 3, p. 687 - 697, 2017. Available from: <http://www.scielo.br/pdf/rcaat/ v30n3/1983-2125-rcaat-30-03-00687.pdf >. Acessed: Set. 5, 2017. doi: 10.1590/1983-21252017v30n317rc.

WICKHAM, H. ggplot2: Elegant Graphics for Data Analysis Springer-Verlag. New York, 2009.

YAN, W. GGEbiplot-a Windows application for graphical analysis of multienvironment trial data and other types of two-way data. Agronomy Journal, v. 93, n. 5, p. 1111-1118, 2001. Available from: <https:// dl.sciencesocieties.org/publications/aj/abstracts/93/5/1111>. Acessed: Set. 12, 2017. doi: 10.2134/agronj2001.9351111x.

YANG, R.-C. et al. Biplot analysis of genotype $\times$ environment interaction: Proceed with caution. Crop Science, v. 49, n. 5,p. 1564-1576,2009.Available from: <https://dl.sciencesocieties.org/publications/cs/abstracts/49/5/1564>. Acessed: Set. 12, 2017. doi: 10.2135/cropsci2008.11.0665. 